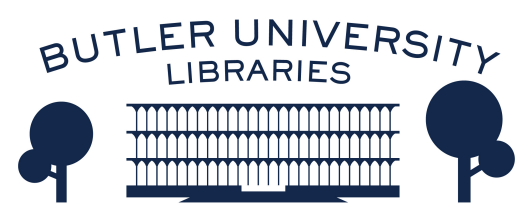

Journal of Hindu-Christian Studies

January 2004

\title{
The Intra- and Inter-Religious Conversions of Nehemiah Nilakantha Goreh
}

Jon Keune

Follow this and additional works at: https://digitalcommons.butler.edu/jhcs

Part of the Religion Commons

\section{Recommended Citation}

Keune, Jon (2004) "The Intra- and Inter-Religious Conversions of Nehemiah Nilakantha Goreh," Journal of Hindu-Christian Studies: Vol. 17, Article 8.

Available at: https://doi.org/10.7825/2164-6279.1317

The Journal of Hindu-Christian Studies is a publication of the Society for Hindu-Christian Studies. The digital version is made available by Digital Commons @ Butler University. For questions about the Journal or the Society, please contact cbauman@butler.edu. For more information about Digital Commons @ Butler University, please contact digitalscholarship@butler.edu. 


\title{
The Intra- and Inter-Religious Conversions of Nehemiah Nilakantha Goreh ${ }^{1}$
}

\author{
Jon Keune
}

THE life of Nilakantha Goreh contains a wealth of inter-religious and cross-cultural encounters, yet surprisingly little has been written about him. Goreh (1825-1895) was a traditionally educated Chitpavan Brahmin, growing up outside the pale of British education and British-influenced Hindu reform movements. ${ }^{2}$ His name is best known now for how his initially staunch and public opposition to Christianity slowly gave way until he finally was baptized in 1848 . What little scholarship there is on Goreh has tended to either focus on or view his whole life in light of his inter-religious conversion. $^{3} \quad$ Although Goreh's interreligious conversion was undeniably crucial and worthy of attention, it was neither an isolated, aoristic incident in his life nor a dramatic life-climax followed by forty years of denouement. . Attending narrowly to his inter-religious conversion risks highlighting only disjunction in the event and neglecting continuities that ran throughout his life. This essay attempts to redress this neglect by proposing a more holistic view of Goreh's religious life. ${ }^{4}$ I also hope this discussion might lift up Goreh further as a fascinating figure in the history of HinduChristian encounter who merits further attention.

Three trends arise consistently in the course of Goreh's religious life: 1) obsession with locating religious orthodoxy, 2) spiritual restlessness and doubt, and 3) a sense of "holiness" or ascetic saintliness. These three trends connect and clarify the important religious changes in Goreh's life. In recognizing these trends, one can better appreciate the motivations that provoked Goreh's institutional itinerancy more than if Goreh's inter-religious conversion is seen only as an overriding disjunction in his life. Before entering into an analysis of the trends, some cursory knowledge of Goreh's life is necessary.

\section{Overview of the Conversions}

In the course of Goreh's life, not one but four significant religious conversions stand out. "Conversion" in this paper connotes the public crossing of religious institutional boundaries. This conceptually involves adopting new authorities as normative and socially involves connecting with new groups of people. In observing trends in Goreh's conversions, I focus attention on intellectual and spiritual aspects that are vitally present and influential for him, as I believe this approach to be the most fruitful matrix in which to understand Goreh's life.

Nilakantha Goreh was born in 1825 and grew up in a wealthy, orthodox Chitpavan Brahmin family in Banaras. His grandfather had moved there from Ratnagiri (on the Konkan Coast) and found ministerial work with the nawab of Bundelkand. ${ }^{5}$ Due to his father's erudition and the family's wealth, Nilakantha received a private education at home rather than being sent to a British- or missionary-run school. Following his scholarly father's lead, Nilakantha excelled

Jon Keune earned his B.A.. from Saint Olaf College in religion and philosophy, and his Master of Divinity from Princeton Theological Seminary. He conducted the research for this paper under the auspices of a Fulbright Scholarship in India and a Spalding Trust (UK) grant in London. 
in his studies, earning the titles pandit and shastri while still a teenager. At age 19 Goreh broke from his Shaivite upbringing and turned his devotion to Vishnu. He cited two explicit reasons for this first of his multiple conversions. First, he says that Vishnu's supremacy was professed in the "more venerable and more ancient authorities of the Hindu religion as well as the rites and ceremonies of it" and second, "the great Shankaracarya and his immediate followers were plainly Vishnu. worshippers, and Shiva is almost ignored in their systems. ${ }^{.6}$ Local pandits disapproved of this change, as they in Goreh's words "could not enter into such criticism." " One pandit, in heated argument with Goreh over immorality in Shiva's behavior, warned provocatively that if Goreh continued on his path of error, he might one day become a mleccha (barbarian) Christian. ${ }^{8}$

History proved the pandit correct, but only after a long, involved interlude. Goreh's first contact with Christianity evoked in him great animosity. As an act of devotion to his new deity, Vishnu, Goreh vowed to drive out Christian street preachers who were becoming increasingly active and provocative in Banaras. ' To this end he approached. William Smith, a Church Missionary Society (CMS) missionary, hoping to engage him in argument. Smith gave him a book recently published by the mission-minded Bengal Civil Servant, John Muir. Muir's Matapariksha, written in Sanskrit so as to appeal to Hindu intelligentsia, attempted to demonstrate the superiority of Christianity over Hinduism on grounds that there is more and better evidence for the miracles in the Bible than those in the Vedas. ${ }^{10}$ Soon thereafter Goreh countered with his own Sanskrit response, the Shastratattvavinirnaya. ${ }^{11}$ He argued that Muir's hermeneutical approach to Hindu texts was terminally and problematically predisposed toward doubt rather than belief. ${ }^{12}$ Christians who read the Vedas place their worldly reason (tarka) above faith (shraddha), and therefore they arrive at faithless, wrong conclusions.

Over the next three years Goreh continued to argue with Smith. Time and again in their early conversations Goreh demonstrated his intellectual prowess, sometimes to the extent that Smith privately had to admit Goreh's arguments felt superior to his own. ${ }^{13}$ However, Smith had no intention of out-arguing Goreh just as he had no interest in learning the Hindu tradition that Goreh wanted to share. Smith resisted Goreh's requests to "read the Shastras" and continued to insist that Goreh study the Bible. ${ }^{14}$

In November of 1846, Goreh began showing obvious signs of personal struggle over religious questions. ${ }^{15}$ Throughout the next year, Goreh probed local pandits for assistance in his arguments and questions but found no satisfaction in this. By the end of 1847 , Goreh confessed his inclination to become a Christian. After several months of self-doubt and discouragement from relatives, on March 14, 1848, Goreh evaded his guardians and was baptized by a missionary in a nearby town. Immediately after his family discovered this second of Goreh's conversions, they performed his ghatasphot - his effective and dishonorable social death as a Hindu.

In the next nine years, Goreh traveled widely around India and spent sixteen months in England, primarily as the personal tutor of the recently deposed young maharaja of Lahore, Duleep Singh. If Goreh had any illusions about an idyllic Christian England, this trip dispelled them. "If what I have seen in London is Christianity, I want to go back to India; if that is Christianity, I am not a Christian." 16 Goreh returned to India in 1855 to translate texts and teach languages to CMS missionaries in Banaras. $\mathrm{He}$ eventually became restless again, exercised with doubts about the divinity of Jesus. This onslaught marks the beginning of Goreh's third conversion.

He traveled to Calcutta in 1857 to consult Dr. William Kay, Principal at 
Bishop's College, about the orthodoxy of doctrines regarding Jesus' divinity. Apparently for the first time, Goreh noticed doctrinal differences among Christian groups in India. Kay introduced Goreh to the writings of Oxford Movement theologian, Edward Pusey, and Goreh began discerning fundamental theological disagreements between the evangelical CMS and more ecclesiocentric Anglicans.

Goreh's discontent with the doctrinal position of the CMS grew until in October of 1864 Goreh finally withdrew his services from them. In Kanpur, Goreh joined J. R. Hill, a missionary affiliated with the theologically centrist Society for the Propagation of the Gospel (SPG). Hill introduced Goreh to Keshab Chandra Sen, who was giving public lectures in the town then in 1866. This timely meeting drew Goreh's attention away from refutations of classical Hindu philosophy and towards engaging contemporary Hindu reformist ideas. A further step came in his move to Calcutta, where he studied to become ordained and work for the Church of England in India. After one and a half years of studying at Bishop's College and debating publicly with Sen and the Brahmo Samaj, Goreh was ordained as a deacon of the Church of England - his third conversion.

A fourth conversion can be further discerned in the development of Goreh's relationship with an Anglican monastic order, the Society of St. John the Evangelist (SSJE). After several years of admiring them from afar, he approached the SSJE mission in Bombay in 1875 and took the requisite steps to enter the order. While Goreh's longing for an ascetic, spiritual -lifestyle attracted him to the SSJE, the spiritual praxis of the order left Goreh unfulfilled and even more confused. ${ }^{17}$ Ten years later, under the weight of a new load of doubts about his beliefs and worthiness, Goreh withdrew from the order (never having gone beyond the status of novice) to live out the remaining nine years of his life informally with the SSJE as he wrote tracts promoting Christian doctrines.

As should be apparent, Goreh was an active religious man throughout his whole life. This being the case, it is helpful to identify three trends that persist throughout his life that in my opinion help clarify some of Goreh's changes.

\section{Searching for Orthodoxy}

Goreh's opponents and critics have proposed dubious psychological and material reasons for his conversions, ${ }^{18}$ but Goreh's public and private writings strongly testify to intellectual and heart-felt compulsions. Deeply introspective and selfconsciously cerebral, Goreh seems to have literally agonized over decisions, trying to discern what he could honestly and correctly believe. Standing out in his reasoning are appeals to various forms of religious authority. Goreh remains clear about the grounds upon which he makes decisions.

In his first conversion, one appeal dominates his arguments: based on the "more venerable and more ancient authorities of Hindu religion," Vishnu appeared superior to Shiva. Goreh mentions his disagreements with local pandits on this point. These "authorities" he refers to are texts. His appeal to Shankaracarya's true worship also is based on textual investigation. In his refutation of Muir, Goreh grounds his argument in the authority of Hindu scripture over the power of human reason. In his debates later in life with the Brahmo, Prarthana and Arya Samajs, the Christian Goreh consistently argued that these Hindu reformists did not properly read their own scriptures. Goreh's insistence on the orthodoxy and normativity of a particular strand of Hindu tradition (and their respective texts) continued even after he left that tradition. ${ }^{19}$

This primacy of scriptural authority holds through his second conversion. Monier-Williams (with whom Goreh corresponded) writes of Goreh, "He does not 
48 Jon Keune

attribute his own conversion to any human instrumentality, although there was a certain Mr. Smith at Banaras with whom he was in the habit of arguing. $\mathrm{He}$ traces his conversion entirely to his own reading and the grace of God." 20 Goreh describes his own conversion as almost exclusively textbased.

Goreh writes that he was first struck by the Sermon on the Mount while reading the Bible in order to refute Muir. Jesus' words surprised Goreh; they seemed to him too "holy" to be merely human, shockingly located in a mleccha text! ${ }^{21}$ Goreh's attraction to the Sermon on the Mount, to my knowledge, does not follow common evangelical strategies of missionaries influenced by British natural theology and evidentialism. Goreh perused the Bible relatively free of missionary guidance. While the Sermon itself was not a piece of the evidentialist apologetic, the notion of divine status did play an important role in that theology. If one could establish that Jesus' words were of divine origin, argued Paley and Muir (who had not yet applied historico-critical tools to his own faith), then one must acknowledge the whole Bible as divine revelation. Perhaps Goreh's discovery of the Sermon, in the presence of evidentialist critique and ongoing engagement with the Bible and Smith, took hold in his mind and gradually persuaded him that the Bible held more authority than the Vedas. ${ }^{22}$ Shraddha (faith), of which Goreh spoke so confidently in the Shastratattvavinirnaya, gradually faded from Goreh's active vocabulary and ceased to appear in his writings.

Goreh's third conversion demonstrates his continued obsession with finding authority. Interestingly, when Goreh became concerned about accepting the correct doctrine of Jesus' divinity, he did not find a conclusive answer in the Bible but rather sought out a person whom he saw as authoritative. Upon discovering the plurality of Christian biblical interpretations, Goreh had no normative background from which to make his own judgments about interpretation. His norm, so he thought, had been the Bible itself. To orient himself correctly in interpreting the Bible, Goreh sought the help of another person.

In the course of his interaction with William Kay, Goreh found some intellectual satisfaction. It is likely that Pusey's systematic theology strongly appealed to Goreh's rationality more than the theology espoused by the CMS. ${ }^{23}$ Pusey introduced Goreh to a new form of authority - the ecclesiastical body of the Anglican Church. Goreh's perception of orthodoxy gradually shifted away from the Bible of the evangelicals to the Church of the mainstream Anglicans.

Goreh testifies clearly that it was his intellect that drove him to find an authority he could trust, to the extent that other parts of his life were sacrificed to this obsession. While his conversions and contexts differ, this particular trend continues throughout. It may be the dominance of this trend that contributes to a continuous dissatisfaction in another facet of his religious life.

\section{Spiritual Discontent and Doubt}

There is little extant information as to Goreh's spiritual contentment or discontentment as a Hindu. Thus I make some extrapolation to propose spiritual discontent as a lifelong trend for Goreh, although I believe this move to be warranted. His inter-sampradaya conversion testifies to the fact that he was clearly dissatisfied and found reason to redirect his devotion, even in the face of strident opposition from people around him.'

The degree of unrest Goreh felt during his more-documented Christian life is striking and readily apparent. At Goreh's deathbed, his caretaker recorded and explained a statement by him:

I have made one request to God for forty-two years, and $\mathrm{He}$ has not granted it me." This prayer was for 
joy in religion. He had been converted by those who lay great stress on this feeling, and he longed for it with no common desire, but God never seemed to hear him. He was very saintly, but utterly joyless. $^{24}$

Goreh himself attests to his internal dis-ease in personal letters:

When I have doubts about certain things, it seldom happens that they are removed by others. I myself get out of them. It was not by the persuasion of any missionaries that I was led to embrace Christianity. After I became a Christian, I was troubled and tried very severely by these doubts... ${ }^{25}$

Throughout his life, Goreh never ceased to be troubled by religious doubts and spiritual discontent. Gardner is clearly uncomfortable with Goreh's doubts, as they detract from his hagiographic project to laud the Christian faith of this famous convert. Although Gardner attempts to bracket away the doubts, he preserves substantial pieces of Goreh's private correspondence. From this correspondence and from the testimony of friends, it is obvious that Goreh's doubts were a source of lifelong anxiety. No information 'comes down through history about this aspect of Goreh's childhood, although one may discern elements of doubt/uncertainty in the time leading up to and persisting beyond Goreh's second conversion. He writes:

When my mind became inclined to embrace Christianity I was kept for a long time in the state of doubts and perplexity, and it was not by coming to an unquestioning and clear decision that I at last was resolved to receive baptism, but from the consideration that I could not forever go on questioning, but must decide one way or the other, and that as I could not make up my mind not to become Christian, so I must make up my mind to become a Christian. But though I took the step and received baptism, yet doubts and perplexities have never left me. ${ }^{26}$

Goreh recognized that his discontent originated in a tension between reason and trust, with reason being undeniably dominant for him. In a revealing note to a Father Page (SSJE), Goreh warns against converting on rational grounds alone. Since Goreh had done just that, he felt his own Christian faith was consequently weak. ${ }^{27}$

The very shraddha that Goreh abandoned in his inter-religious (second) conversion may have been the thing he missed most as a Christian. Goreh never arrived at a comfortable balance of faith and reason.

Goreh's discontent later in life could be related also to the trouble that he had with Western forms of spirituality. When he was in the initial stages of joining the SSJE, Fr. Page prescribed for him a month of silent retreat and contemplation of a book of meditations. Goreh confessed, "I could do nothing with it," 28 so he simply kept silent and waited for the retreat to end. Two years later, Goreh repeated the experience at a retreat in England, in the process of becoming a novice in the SSJE. The result was the same. The kind of spirituality the SSJE sought to foster in Goreh simply did not suit him.

Goreh by no means lacked spiritual impulses. No information remains as to his Hindu praxis, although he recounted fondly a daily devotional routine of reciting Hindu scripture. ${ }^{29}$ Throughout Goreh's Christian life, he indicated a strong attraction to an ascetic way of life. Goreh's sense of holiness, having both moral and spiritual dimensions for him, was also connected with his identity as an Indian. Despite his 
efforts to live this out in a Christian form, it is my contention that he never found a way to reconcile his spiritual longings with the forms of Christianity he encountered during his lifetime. ${ }^{30}$ According to his own letters and conversations, he never fulfillingly found what he was looking for.

Although Goreh spent a great deal of his time associating with British missionaries and clergy, he retained a strong Indian identity. $\mathrm{He}$ discerned the futility of particular missionary strategies, especially the critique of Hindu "idolatry."31. His conversion to Christianity, while changing his perspective on Hindu tradition, did not bring him to denounce it as exclusively evil. Rather, Goreh opined that of all the ancient sages in the world prior to Jesus Christ, Indian rishis had the most knowledge of true religion. ${ }^{32}$ As a Christian he mentioned briefly that the language of the Shrimadbhagavata "charms me even now." $" 33$ Furthermore he asserted, "Christianity is oriental, though Westemers have converted to it. ${ }^{, 34}$ Goreh never ceased to engage the religious and cultural tradition of his early life and ancestors. These factors firmly establish Goreh as a remarkable, liminal figure in $19^{\text {th }}$ century HinduChristian encounter. Perhaps this liminality prevented Goreh from finding total fulfillment in any of the religious contexts he encountered. With no role models to follow and few peers to converse with, Goreh was truly on his own.

\section{Sense of moral life or "holiness"}

As mentioned briefly above, Goreh sometimes referred to a "holiness" when explaining himself. $\mathrm{He}$ also spoke and wrote about asceticism as being an important virtue for Christians in India. This language recurs with such frequency throughout his life that it merits reflection. ${ }^{35}$ Goreh, after his first, intra-Hindu conversion, argued with a pandit over the immorality of Shiva's behavior. He could not have been thinking within Christian categories, for he had not yet encountered Christian or British thought in any influential way. This criterion for proper belief and religion informed his judgments as a Hindu.

Then, reading the Bible as he prepared to refute it, Goreh reports his fascination with the Sermon on the Mount because of its "holiness." " That this flag went up unintentionally during Goreh's reading requires that the flag existed prior to his reading. Thus the beginning of Goreh's inter-religious conversion indicates some strong continuity with his Hindu roots.

In his first major publication as a Christian, Goreh writes that Christianity is superior to Advaita Vedanta (which Goreh, like many of his contemporary orientalists and Hindu scholars, took to be the epitome of Hindu thought) because Christianity has more to say about $\sin$ and virtue ${ }^{37}$ and because it offers better criteria for discerning between good and evil. ${ }^{38}$

As part of his arguments against Hindu reform movements, Goreh (like Paley) held that one important sign of true religion is that its founder should behave in an exemplary, moral way. Goreh argued that Krishna's licentious behavior disqualifies him from such consideration whereas Jesus' actions are impeccable. ${ }^{39}$ His understanding of holiness here is clearly influenced by Paley's evidential theology yet still connects to his Hindu background. ${ }^{40}$ This Anglican argument parallels Goreh's concern about Shiva's behavior, when the Hindu Goreh converted between sampradayas.

Goreh's concern about moral behavior tied in closely with an assumption that a holy person ought to lead a simple, even ascetic life. This moral/ascetic concern appears again as Goreh was drawn toward the SSJE. He states that he longed for a more ascetic discipline in his life and saw the order as a way to accomplish that. ${ }^{41} \mathrm{By}$ this point in his life, Goreh had written on multiple occasions that in all his Christian life he had been most content when living spartanly with Page as they traveled in north 
India to various mission projects. Goreh embodied a self-denial that went beyond what he found most British Christians around him doing. Thus it is likely that Goreh was drawing on his formation in earlier years as a Hindu.

In a speech at the 1877 Mission Conference in Oxford, Goreh expounded more clearly on how he understood asceticism to be part of the Indian ideal of holiness. He strongly recommended that future missionaries from the West adapt their lifestyles in India accordingly. ${ }^{42}$ This concern for holiness, obviously linked to morality, lies powerfully in the background of Goreh's actions, both as a Christian and as a. Hindu. As this impulse persisted throughout his life, through each of his religious affiliation changes, one again observes continuity in Goreh's life throughout his conversions.

\section{Conclusion}

Academic discussion of religious conversion has tended to emphasize the disjunctive quality of these occurrences to assist sociological, theological and taxonomic analysis. While useful in some ways, this approach is prone to overlook or at least downplay continuities that endure through conversions as a process through time. If focusing on conversion entails reducing the convert to a disjunctive event, then one ought to be aware of what broader perspective and deeper understanding are precluded thereby.

In this paper, I have highlighted three trends in the life of a famous $19^{\text {th }}$ century "convert" which provide a deeper understanding of this man's religious development. ${ }^{43}$ In light of the complexity of Goreh's situation and thought, following the well-worn paths of thinking about conversion oversimplifies his actions and reduces him to the superficial, provocative status of "convert." I have tried to show that Goreh's life and thought exceed such a simplistic understanding of conversion and merit further research.

A broad, comprehensive understanding of religious conversion also may have more than only explanatory value. Employing a simplistic understanding of conversion feeds the inflammatory potential of this volatile topic. In contrast, recognizing that at least some religious conversions contain great continuities as well as disjunctions may contribute both to a more nuanced understanding of religious conversion and ultimately to less oppositional thinking about religious plurality.

\section{Notes}

1. The author warmly thanks Dr. Richard Young of Princeton Theological Seminary and Dr. Andrew Walls of the University of Edinburgh for their helpful guidance and encouragement in this project. The author also extends his gratitude to the Spalding Trust for their assistance, and to Dr. Morley James Stuart and Brother James Simon for their hospitality at St. Edward's House.

2. In contrast, contemporaries of Goreh in northern India Krishna Mohan Banerjee (18131855), Lal Behari Day (18241894), and Brahmabandhab Upadhyay (1861-1907) - all attended British or missionary schools and were quite involved in the synergy of the Bengal Renaissance. Goreh's education and early life were quite different.

3. E.g. C.E. Gardner, The Life of Father Goreh (London: Longmans, Green and Company, 1900); Robert E. Speer, Studies in Missionary 
Leadership: The Smyth Lectures of 1913 (Philadelphia: Westminster Press, 1914). A refreshingly critical and thorough approach is taken by Richard Fox Young, who observes Goreh's early Sanskrit apologetical writings. Cf. Richard Fox Young, Resistant Hinduism: Sanskrit Sources on Anti-Christian Apologetics in Early Nineteenth Century India (Vienna: Institüt für Indologie der Universität Wien, 1981).

4. My approach, focusing on continuity, fits well with recent discussions of conversion by Lewis Rambo and Andrew Walls. Cf. Lewis Rambo, Understanding Religious Conversion (New Haven: Yale University Press, 1993). Andrew F. Walls, The Missionary Movement in Christian History (Maryknoll NY: Orbis Books, 1996), esp. p. 28.

5. The most comprehensive resource for information on Goreh's life remains C. E. Gardner's biography/ hagiography. My description here draws on Gardner, supplemented by Goreh's own writings and a biographical pamphlet written by two of Goreh's contemporaries and friends. Cf. James Henry Lord \& Balwant Sadashiv Lotlikar, $A$ Short Sketch of the life of Rev. Nehemiah Goreh (Bombay: Printed at Bombay Education Society's Steam Press, 1895).

6. Gardner, pp. 35-6.

7. Ibid.
8. Ibid.

9. William Smith, Dwif (London: James Nisbet and Co., 1850), p. 37.

10. This line of argument, "evidentialism," was common Anglican theology of the day, drawing especially on the teaching and writing of William Paley. Cf. William Paley, Natural Theology: or Evidences of the Existence and Attributes of the Deity (New York: Sheldon, 1879).

11. In Resistant Hinduism, Young lays out the arguments between Muir and Goreh in much more detail. Young, pp. 73-80 on Muir and pp.153-161 on Goreh.

12. Nilakantha,

Shastratattvavinirnaya, ed. S.L. Katre (Ujjain: Scindia Oriental Institute, 1951), 3:64-5.

13. Gardner, p. 45.

14. Tbid., p. 40, cited in a letter from Goreh to "a Christian friend," some time after Goreh's baptism.

15. Cf. Paul Griffiths' insight on refutational commentary, "It's scarcely possible to read a work with the closeness, clarity, and care required of a commentator without having it enter your soul - even if this is not your intention." Paul Griffiths, Religious Reading (Oxford: Oxford University Press, 1999), p. 94 . 
16. Cited in Max Müller, Auld Lang Syne (New York: C. Scribner's Sons, 1898), p. 50.

17. Gardner, p. 300

18. The modern re-discoverer and editor of the Shastratativavinirnaya, S. L. Katre, expresses strong doubts in his introduction to the work, about the integrity of Goreh's inter-religious conversion. In Baldeva Upadhyaya's Kashi ki Panditya Parampara (Pandit Traditions of Banaras) (Varanasi: Vishvavidyalaya Prakashan, 1994), pp. $1059-1065$ is a short, disappointed overview of Goreh's life. A modern Marathi novel, V. G. Kanitkar's Horpal (Scorched) (Kulkarni Granthagar: Pune, 1971), also presents Goreh's Christian life story in strongly negative terms.

19. Goreh's perception of Hindu orthodoxy reveals another interesting feature of his background. In The Existence of Brahmoism, Goreh confesses his abiding appreciation for the Shrimadbhagavata, but wonders how the author can laud bhakti when moksha is the real goal of Hinduism. As mentioned in the introduction, the young Goreh's Hindu education occurred mainly beyond the influence of Western historico-critical scholarship and academic taxonomy of the darshanas. Nehemiah Goreh, The Existence of Brahmoism is Itself a Proof of the Divine Origin of Christianity (Allahabad: North Indian Tract Society, 1889), 22.

20. Gardner, p. 43.
21. Ibid.

22. While Goreh admitted no human instrumentality in his conversion, the frequent meetings with Rev. Smith could. not have been inconsequential. One must acknowledge the significant amount of time involved during which Goreh engaged the Bible in various capacities and with various motives-almost four full years.

23. In a personal conversation in the spring of 2000, Andrew Walls proposed that Pusey's project of reviving the study of patristics also may have appealed to Goreh's appreciation of "more ancient and more venerable authorities."

24. Gardner, pp. 380-381. Gardner includes here a reprint of the memoirs of Goreh's primary caregiver shortly after Goreh's death.

25. Ibid., p. 96.

26. Ibid., p. 179. Goreh to SSJE founder, R. M. Benson, in 1875.

27. Cited in Young, p. 172.

28. Gardner, p. 169, excerpted from Goreh's private correspondence.

29. Ibid., p. 214

30. Here one might note the remarkable differences between Goreh and two Marathi contemporaries who converted, Narayan Vaman Tilak (18621919) and (Pandita) Ramabai Saraswati (1858-1922). Tilak 
and Ramabai both speak of having two major Christian conversions - first of the intellect, and a few years later of the heart. Goreh never speaks about a conversion of the heart. Also noteworthy are the differences in how Goreh bound himself strictly to an ecclesiastical institution, whereas Tilak kept more distance (and independence) and Ramabai blazed her trails away from established Christian institutions.

31. Rev. N. Goreh, "Rev. N. Goreh and Sir M. Monier-Williams," Indian "Church Quarterly Review 13:2 (April 1901), 223.

32. Nehemiah Goreh, Four Lectures Delivered in Substance to the Brahmos in Bombay and Poona in April and July 1875 (Bombay: Byculla Educational Society Press, 1875), p. 3.

33. Nehemiah Goreh, Existence of Brahmoism itself is Proof... (Allahabad: North Indian Tract Society, 1889), p. 20.

34. Ibid. Goreh may have drawn this notion from K. C. Sen or P.C. Mazoomdar, but I have thus far found no explicit link. Nonetheless, given his contact with Sen I find it quite likely that Goreh was influenced by him on this point.

35. I am indebted to Mark Thomsen of the Lutheran Theological Seminary at Chicago for help in developing this insight.
36. Gardner, p. 42.

37. Nehemiah Nilakantha Goreh, Rational Refutation of the Hindu Philosophical Systems, Fitz-Edward Hall (Calcutta: Bishop's College Press, 1862), p. 275.

38. Ibid., p. 277.

39. Nehemiah Goreh, The Existence of Brahmoism, p. 12.

40. Goreh's $A$ Letter to the Brahmos from a Converted Brahman of Benares (1868) is an exemplary text revealing Goreh's criteria for comparing the value of various religions, which he saw eventually leading to the supremacy of Christianity.

41. St. Stephen's Parish Magazine (Lewisham), 'vol. 8:1, January 1877, 'p. 4 , citing a talk given on November 2, 1876 at the parish.

42. N. Goreh, Missionary Brotherhoods (in Mission Conference Report, of . Second Missionary Conference in Oxford, May 1877), p. 66.

43. Lewis Rambo (cf. n. 4) notes that if $a$, convert changes multiple times in his or her life, this should be no surprise. "I would argue that people who convert and remain the same are not really on a spiritual path of transformation," p. 162. 